\title{
Pemodelan Kinetika Pengeringan Beberapa Komoditas Pertanian Menggunakan Pengering Inframerah
}

\author{
Drying Kinetics Modeling of Agricultural Commodities Using Infrared Dryer \\ Nok Afifah, Ari Rahayuningtyas, Seri Intan Kuala
}

\begin{abstract}
Pusat Pengembangan Teknologi Tepat Guna (PPTTG-LIPI), J1.K.S.Tubun No. 5 Subang, Jawa Barat 41211, Indonesia Email: syabiljafa2008@gmail.com; arirahayuningtyas@gmail.com; seri.kuala.sk@gmail.com
\end{abstract}

Submisi: 22 Januari 2016; Penerimaan: 27 Juli 2016

\begin{abstract}
ABSTRAK
Studi kinetika pengeringan telah dilakukan pada beberapa komoditas pertanian menggunakan pengering inframerah pada temperatur $60^{\circ} \mathrm{C}$. Penelitian ini bertujuan untuk menetapkan model pengeringan dan effective moisture diffusivity yang menunjukkan karakteristik pengeringan irisan singkong, irisan pisang dan polong kacang tanah. Perlakuan yang digunakan adalah jenis komoditas pertanian (umbi singkong, buah pisang, dan polong kacang) pada dua level kapasitas $12 \mathrm{~kg}$ dan $24 \mathrm{~kg}$. Pengeringan dilakukan dengan menata bahan pertanian di atas loyang masing-masing sebanyak 0,5 kg dan $1 \mathrm{~kg}$ untuk perlakuan kapasitas $12 \mathrm{~kg}$ dan $24 \mathrm{~kg}$. Sebanyak 24 loyang dimasukkan ke dalam pengering dan setiap jam diambil sampel untuk dianalisa kadar airnya dengan metode gravimetri. Data diujikan dengan empat model pengeringan dan analisis regresi non-linear digunakan untuk menentukan parameter model. Nilai rasio kandungan air eksperimental dan hasil prediksi model selanjutnya dibandingkan berdasarkan koefisien determinasi $\left(\mathrm{R}^{2}\right)$. Hasil penelitian menunjukkan bahwa kenaikan kapasitas pengeringan akan menurunkan laju pengeringan untuk semua komoditas pertanian. Model Page terlihat paling baik untuk menggambarkan perilaku pengeringan bahan-bahan pertanian tersebut. Nilai difusivitas efektif kandungan air berkisar pada $1,34 \times 10^{-10} \mathrm{~m}^{2} / \mathrm{detik}-3,23 \times 10^{-10} \mathrm{~m}^{2} / \mathrm{detik}$.
\end{abstract}

Kata kunci: Difusivitas efektif; pisang; singkong; model pengeringan; kacang tanah; kinetika

\begin{abstract}
The drying kinetics study was carried out on agricultural commodities using an infrared dryer at temperature $60{ }^{\circ} \mathrm{C}$. The aim of this study was to determine a drying model and effective moisture diffusivity that showed the drying characteristics of cassava slices, banana slices and groundnut pods. The experiments were conducted at three agricultural commodities (cassava, banana, and groundnut) at two capacity levels of $12 \mathrm{~kg}$ and $24 \mathrm{~kg}$. Drying was done by arranging the agricultural material on tray of $0.5 \mathrm{~kg}$ and $1 \mathrm{~kg}$ for the treatment of $12 \mathrm{~kg}$ capacity and $24 \mathrm{~kg}$ capacity, respectively. A total of 24 trays were inserted into the dryer and every hour sample was taken to analyze the water content by gravimetric method. Data was fitted to four drying models and non-linear regression analysis was used to determine model parameters. The models were compared based on their coefficients of determination $\left(\mathrm{R}^{2}\right)$ between the experimental and predicted moisture ratios. The results showed that the increase of drying capacity would decrease the drying rate for all agricultural commodities. The Page model was showed to the best for describing the drying behaviour for these agricultural products. Effective moisture diffusivity ranged between $1.34 \times 10^{-10} \mathrm{~m}^{2} / \mathrm{s}-3.23 \times 10^{-10} \mathrm{~m}^{2} / \mathrm{s}$.
\end{abstract}

Keywords: Effective moisture diffusivity; banana; cassava; drying model; groundnut; kinetic 


\section{PENDAHULUAN}

Sektor pertanian memegang peran penting di Indonesia karena sebagai negara agraris. Umbi-umbian, serealia, kacangkacangan, sayuran, dan buah-buahan merupakan komoditas pertanian yang tersebar luas di Indonesia. Ubi kayu (Manihot utilissima) merupakan tanaman pangan dengan tingkat produksi terbesar kedua setelah padi (Silvia dan Yuwana, 2012). Diantara berbagai jenis buah-buahan, pisang (Musa paradisiaca) merupakan komoditas buah dengan tingkat produksi tertinggi (Hanum dkk., 2012). Tingkat produksi kacang tanah (Arachis hypogeae L) menduduki urutan kedua setelah kedelai (Saputra, 2014). Pada tahun 2014, produksi singkong sekitar 23,44 juta ton umbi basah, kacang tanah sekitar 638,90 ribu ton biji kering, dan produksi tanaman buah pisang pada tahun 2014 sekitar 6,86 juta ton (BPS, 2015).

Ubi kayu merupakan komoditas pertanian yang tidak tahan lama karena sifatnya yang sangat peka terhadap investasi jamur dan mikroba lain sehingga masa simpan dalam bentuk segar sangat pendek (Koswara, 2009). Demikian pula buah pisang, dengan kandungan air sekitar $70 \%$ menyebabkan buah ini sangat rentan terhadap kerugian pascapanen dan penurunan berat selama transportasi dan penyimpanan (Faal dkk., 2013). Kerusakan kacang tanah setelah pemanenan diakibatkan serangan mikroorganisme jenis Aspergillus (Saputra, 2014). Pengeringan merupakan salah satu cara untuk menghindari kerusakan-kerusakan komoditas pertanikan akibat mikrorganisme seperti jamur dan bakteri. Pengeringan juga dapat mengurangi berat dan volume produk, meminimalkan kemasan, biaya penyimpanan dan transportasi, dan memungkinkan daya simpan produk di bawah temperatur lingkungan (Brooks dkk., 2008; Doymaz, 2013).

Pengeringan adalah proses yang membutuhkan energi paling intensif dalam industri makanan. Pengeringan inframerah untuk bahan pertanian saat ini menjadi perhatian karena memberikan beberapa keuntungan dibandingkan pengeringan konvensional dalam kondisi pengeringan yang sama. Pengeringan inframerah memberikan produk yang terpapar panas lebih seragam, sehingga menghasilkan produk dengan karakteristik kualitas yang lebih baik, waktu pengeringan lebih pendek, dan efisiensi energi yang tinggi (Nowak dan Lewicki, 2004; Sharma dkk., 2005). Pengeringan infrared adalah salah satu metode terbaik untuk pengeringan lapisan-tipis bahan pertanian (Motevali dkk., 2011 dalam Motevali dkk., 2014). Beberapa produk pertanian yang telah berhasil dikeringkan dengan teknologi inframerah dan/atau mengkombinasikannya dengan proses konveksi diantaranya pisang (Swasdisevi dkk., 2007), padi (Laohavanich dan Wongpichet, 2008), wortel (Botelho dkk., 2011; Doymaz, 2013), dan nanas (Ponkham dkk., 2012).
Beberapa model telah diajukan untuk menganalisis dan mensimulasikan proses pengeringan produk-produk pertanian. Dalam produk berpori-kapiler yang higroskopis, umumnya produk pertanian, kemungkinan mekanisme transportasi kandungan air adalah: difusi cairan, difusi kapiler, difusi di permukaan, aliran hidrodinamik, difusi uap, dan difusi termal (Brooker dkk., 1992 dalam Botelho dkk., 2011). Laju pengeringan meliputi laju pengeringan konstan dan laju pengeringan menurun. Pengeringan produk pertanian pada umumnya terjadi pada periode laju pengeringan menurun (falling rate). Dengan kata lain, laju pengeringan konstan pada produk pertanian terjadi sangat singkat. Difusi adalah salah satu peristiwa paling efektif yang mengendalikan aliran kandungan air dalam bahan. Zogzas dkk. (1996) menerangkan bahwa pengeringan bahan berpori dalam periode falling rate dapat diperkirakan oleh hukum difusi Fick yang kedua. Botelho dkk. (2011) menyatakan bahwa untuk perhitungan teoritis koefisien difusi efektif produk pertanian, beberapa penelitian didasarkan pada teori difusi cairan, dikenal sebagai Hukum Fick Kedua.

Banyak penelitian yang telah dipublikasikan oleh beberapa peneliti mengenai pemodelan pengeringan produk pertanian menggunakan pengering skala laboratorium yang diujikan pada satu jenis komoditas (Kashaninejad dkk., 2007; Laohavanich dan Wongpichet, 2008; Wilaipon, 2013; Faal dkk., 2013). Namun hingga saat ini sedikit informasi yang tersedia tentang kinetika pengeringan beberapa produk pertanian pada skala semi-industri. Peningkatan kapasitas pengeringan akan meningkatkan ketebalan lapisan tipis dalam tiap loyang yang berpengaruh terhadap laju pengeringan (Kajuna dkk., 2001). Selain kondisi udara pengering, jenis, dan komposisi bahan pertanian juga berkaitan dengan laju pengeringan (Fernando dkk., 2011; Aghbashlo dkk., 2011). Tujuan penelitian ini adalah menetapkan model matematik dan effective moisture diffusivity yang dapat menggambarkan kinetika pengeringan irisan umbi singkong, irisan buah pisang, dan polong kacang tanah pada dua kapasitas pengeringan. Model matematik yang digunakan adalah model Newton, Henderson-Pabis, Page, dan Logarithmic.

\section{METODE PENELITIAN}

\section{Bahan dan Alat}

Varietas dan umur panen bahan pertanian yang digunakan dalam penelitian ini adalah ubi kayu varietas Cimanggu (Manihot esculenta Crantz) dengan umur panen 9 bulan, pisang varietas Ambon lumut (Musa paradisiaca var sapientum) dengan umur panen 3 bulan, dan kacang tanah varietas Gajah (Arachys hypogaea L) dengan umur panen 3 bulan. Semua komoditas tersebut diperoleh dari hasil panen 
perkebunan di daerah Dawuan - Subang. Setelah pemanenan bahan-bahan pertanian tersebut dikemas dalam karung dan disimpan dalam ruang tertutup selama 1 hari sebelum digunakan untuk penelitian.

Singkong dan pisang dikupas dan diiris tipis menggunakan mesin slicer dengan ketebalan $3 \mathrm{~mm}$. Irisan dibuat tipis untuk mempercepat proses difusi dan laju pengeringan, biasanya sekitar $2 \pm 1 \mathrm{~mm}$, karena pada irisan yang tebal meskipun pada permukaan terlihat kering tetapi kadar air internal mereka masih akan tinggi (Udoro dkk., 2008; Faal dkk., 2013). Irisan pisang kemudian direndam dalam larutan $2 \%$ natrium metabisulfit $\left(\mathrm{NaS}_{2} \mathrm{O}_{5}\right)$ untuk mengendalikan reaksi pencoklatan enzimatis dan nonenzimatis (Palupi, 2012). Polong kacang tanah dengan diameter rata-rata $5 \mathrm{~mm}$ dibersihkan dari kotoran tanah sebelum dikeringkan.

Alat yang digunakan dalam penelitian ini adalah mesin pengering inframerah tipe tray cabinet (Gambar 1), mesin slicer, timbangan digital, dan desikator. Pengering mempunyai dimensi $2 \times 2 \times 2 \mathrm{~m}$. Bagian dinding terbuat dari styrofoam tebal $40 \mathrm{~mm}$ yang dilapisi plat stainless steel 304 tebal $1 \mathrm{~mm}$ pada bagian dalam, sedangkan dinding bagian luar menggunakan plat aluminium kulit jeruk tebal 0,8 mm. Bagian lantai menggunakan T Block tebal $20 \mathrm{~mm}$ dan menggunakan lapisan yang sama seperti dinding. Alat pengering ini dilengkapi 2 buah kipas di bagian depan dan belakang berukuran 12 inch, 1 buah exhaust fan berukuran 12 inch, 2 buah lubang sirkulasi udara masuk pada bagian pintu, 2 buah rak, dan 1 panel kontrol. Sebagai pemanas menggunakan gasolec tipe S8 dengan pemanas LPG.

Mekanisme pengeringan dilakukan dengan menyalakan burner berbahan bakar LPG yang dihubungkan dengan gasolec. Pada gasolec terdapat kawat frame berbahan logam khusus. Saat gasolec dinyalakan, kawat frame berubah warna menjadi merah, kawat frame akan memancarkan panas dan gelombang infrared. Lapisan dalam dinding ruang pengering

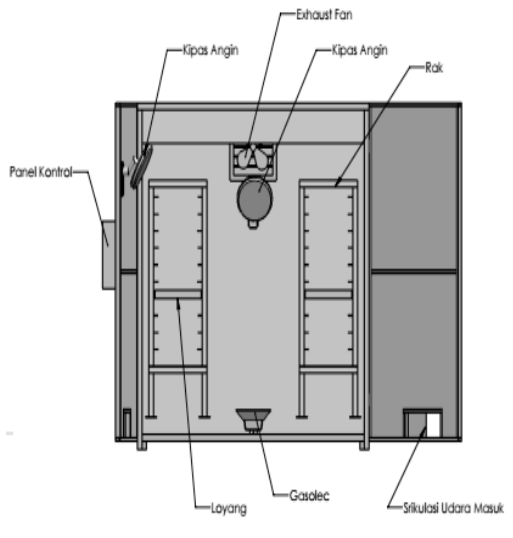

Tampak Depan

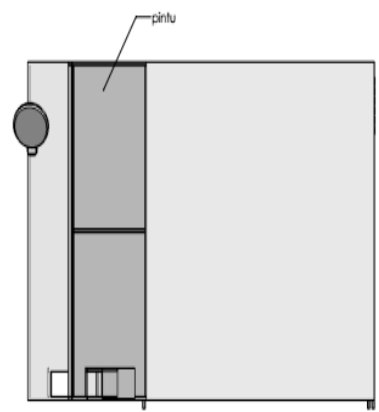

Tampak Samping

Gambar 1. Alat pengering infrared

berupa plat stainless steel akan membantu memantulkan infrared sehingga gelombang infrared yang berada dalam ruang pengering dapat semaksimal mungkin dimanfaatkan untuk proses pengeringan bahan.

\section{Prosedur Pengeringan}

Pengeringan dilakukan pada temperatur dan kecepatan udara tetap. Temperatur diatur pada $60{ }^{\circ} \mathrm{C}$, kecepatan udara masuk 3,4 m/detik, dan kecepatan udara keluar melalui exhaust fan 3,0 m/detik. Untuk meratakan distribusi udara panas dalam ruang pengering digunakan dua buah kipas angin dengan kecepatan $3,9 \mathrm{~m} / \mathrm{s}$ dan $5,6 \mathrm{~m} / \mathrm{s}$.

Rancangan penelitian menggunakan rancangan acak kelompok dengan menggunakan tiga jenis komoditas pertanian pada dua level kapasitas. Bahan pertanian yang digunakan adalah umbi singkong, buah pisang, dan polong kacang tanah. Kapasitas pengeringan dilakukan pada kapasitas $12 \mathrm{~kg}$ dan 24 $\mathrm{kg}$ tiap prosesnya seperti terlihat pada Tabel 1.

Tabel 1. Rancangan penelitian

\begin{tabular}{ccc}
\hline Perlakuan & Jenis bahan pertanian & Kapasitas $(\mathrm{kg})$ \\
\hline SK12 & Singkong & 12 \\
SK24 & Singkong & 24 \\
PK12 & Pisang & 12 \\
PK24 & Pisang & 24 \\
KK12 & Kacang tanah & 12 \\
KK24 & Kacang tanah & 24 \\
\hline
\end{tabular}

Ke dalam setiap loyang dimasukkan bahan pertanian (singkong, pisang atau kacang tanah) sebanyak 0,5 kg untuk rancangan penelitian kapasitas $12 \mathrm{~kg}$ dan $1 \mathrm{~kg}$ untuk rancangan penelitian kapasitas $24 \mathrm{~kg}$. Sebanyak 24 loyang dimasukkan ke dalam pengering dan ditetapkan sebagai jam ke nol. Setiap jam diambil sampel untuk dianalisa kadar airnya dengan metode gravimetri selama 3-5 jam.

\section{Kinetika Pengeringan dan Penentuan Koefisien Difusivitas Efektif}

Beberapa model pengeringan konvensional telah diajukan untuk menentukan hubungaan moisture ratio sebagai fungsi waktu. Dalam penelitian ini digunakan model Newton (Persamaan 1), model Henderson-Pabis (Persamaan 2), model Page (Persamaan 3) dan model logarithmic (Persamaan 4) (Wilaipon, 2013).

$$
\begin{aligned}
& M R=\exp (-K t) \\
& M R=A \exp (-K t) \\
& M R=\exp \left(-K t^{N}\right) \\
& M R=A \exp (-K t)+B
\end{aligned}
$$


Moisture ratio (MR) sampel ditentukan dengan Persamaan 5:

$$
M R=\frac{M_{t}-M_{e}}{M_{i}-M_{e}}
$$

Menurut Diamante dan Munro (1993) dalam Shi dkk. (2008) kadar air kesetimbangan $\left(M_{e}\right)$ relatif kecil dibandingkan dengan kadar air awal $\left(M_{i}\right)$ khususnya untuk pengeringan far infrared. Oleh karena itu secara numerik dianggap nol dalam penelitian ini. Sehingga moisture ratio $(M R)$ dapat disederhanakan menjadi $M / M_{i}$

Dalam pengeringan, difusivitas digunakan untuk mengindikasikan aliran kandungan air dari bahan. Pada periode falling rate, pengurangan kandungan air dikontrol terutama oleh difusi molekular. Koefisien difusivitas efektif ditentukan dengan penyesuaian model matematika untuk difusi cairan sesuai Hukum Fick Kedua (Persamaan 6 hingga Persamaan 9) dengan mengasumsikan bentuk geometri berupa slab, kandungan air hanya bermigrasi secara difusi, mengabaikan penyusutan volumetrik, temperatur kostan, dan waktu pengeringan yang lama (Abano dan Sam-Amoah, 2011; Aregbesola dkk., 2015).

$$
\begin{aligned}
& \frac{\partial M}{\partial t}=D_{e f f} \nabla^{2} M \\
& M R=\frac{8}{\pi^{2}} \sum_{n=0}^{\infty} \frac{1}{(2 n+1)} \exp \left(-\frac{(2 n+1)^{2} \pi^{2} D_{e f f} t}{4 L^{2}}\right)
\end{aligned}
$$

Untuk waktu pengeringan yang lama maka Persamaan (7) dapat disederhananakan menjadi Persamaan (8) dimana persamaan ini dapat disusun ulang menjadi Persamaan (9)

$$
\begin{aligned}
& M R=\frac{8}{\pi^{2}} \exp \left(-\frac{\pi^{2} D_{e f f} t}{4 L^{2}}\right) \\
& \ln M R=\ln \left(\frac{8}{\pi^{2}}\right)-\left(\frac{\pi^{2} D_{e f f}}{4 L^{2}}\right) t
\end{aligned}
$$

Dari Persamaan (9), plot dalam grafik nilai $(\ln M R)$ versus waktu akan menghasilkan garis lurus dengan slop .

\section{Analisis Statistik}

Data dianalisis menggunakan program SPSS 13.0. Konstanta dan parameter-parameter model $(\mathrm{K}, \mathrm{A}, \mathrm{B}, \mathrm{N})$ diestimasi menggunakan prosedur regresi non-linear berdasarkan algoritma Levenberg-Marquardt. Kesesuaian data eksperimental terhadap model dievaluasi menggunakan koefisien determinasi $\left(\mathrm{R}^{2}\right)$ sesuai persamaan (10) (Doymaz, 2013)

$$
R^{2}=1-\left[\frac{\sum_{i=1}^{N}\left(M R_{\text {pre }, i}-M R_{\text {exp }, i}\right)^{2}}{\sum_{i=1}^{N}\left(\overline{M R}_{\text {pre }}-M R_{\text {exp }, i}\right)^{2}}\right]
$$

\section{HASIL DAN PEMBAHASAN}

Bahan pertanian yang dikeringkan diperoleh langsung dari hasil panen tanpa pengolahan awal sehingga mempunyai kadar air yang berbeda-beda antar perlakuan. Kadar air awal basis basah irisan pisang paling tinggi diantara ketiga komoditas ini berkisar pada 74 - 76\%, singkong berkisar pada $60-65 \%$, sedangkan kacang tanah paling rendah berkisar pada $52-60 \%$.

Penurunan kadar air ketiga bahan pertanian tersebut selama pengeringan diperlihatkan pada Gambar 2. Berdasarkan Gambar 2 terlihat bahwa untuk semua jenis bahan pertanian, dengan kenaikan kapasitas pengeringan maka waktu pengeringan yang dibutuhkan untuk mencapai kadar air yang sama menjadi lebih lama. Karena laju alir LPG (sebagai sumber panas) yang masuk tetap untuk semua perlakuan, maka kenaikan beban bahan yang dipanaskan membuat gradien temperatur bahan menjadi semakin kecil. Artinya akan semakin lama air teruapkan dari bahan.

Kenaikan kapasitas membuat lapisan bahan dalam tiap tray semakin tebal dan hal ini akan meningkatkan hambatan dalam proses transfer massa. Untuk pengeringan selama 3 jam, jumlah air yang teruapkan pada irisan singkong kapasitas $12 \mathrm{~kg}$ sebanyak $59 \%$ dan pada kapasitas $24 \mathrm{~kg}$ sebanyak $51 \%$, pada irisan pisang kapasitas $12 \mathrm{~kg}$ sebanyak $38 \%$ dan pada kapasitas $24 \mathrm{~kg}$ sebanyak 33\%, sedangkan untuk polong kacang tanah kapasitas $12 \mathrm{~kg}$ sebanyak $32 \%$ dan pada kapasitas $24 \mathrm{~kg}$ sebanyak $25 \%$.

Beberapa penelitian tentang ketiga bahan pertanian ini telah dilakukan, diantaranya oleh Wilaipon (2013) yang memperlihatkan pengeringan $2,5 \mathrm{~kg}$ singkong menggunakan hot-air microwave oven pada temperatur $70{ }^{\circ} \mathrm{C}$ dan $80{ }^{\circ} \mathrm{C}$ membutuhkan waktu 5-5,3 jam untuk menurunkan kadar air $47 \%$. Pengeringan $120 \mathrm{~g}$ irisan pisang dengan ketebalan $5 \mathrm{~mm}$ menggunakan cabinet dryer (Sanyo OMT oven)

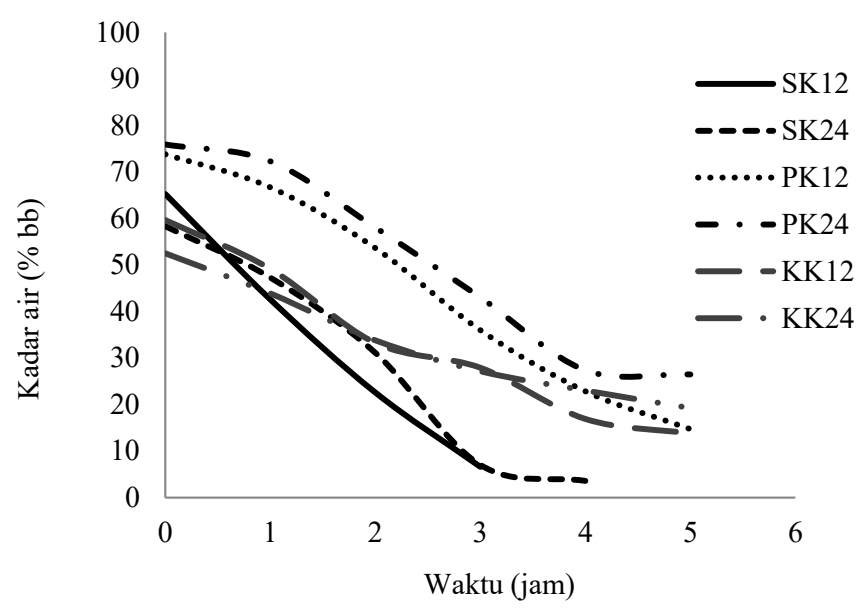

Gambar 2. Pola penurunan kadar air singkong, pisang, dan kacang tanah 
pada temperatur $60{ }^{\circ} \mathrm{C}$ membutuhkan waktu 15 jam untuk mengurangi kadar air dari 75\% menjadi 20\% (Abano dan Sam-Amoah, 2011). Hasil penelitian Ahmad dan Mirani (2012) menunjukkan pengeringan polong kacang tanah menggunakan mobile flat-bed dryer dengan tenaga diesel 7,4 kW membutuhkan waktu 2,4 jam untuk menurunkan kadar air $1.818 \mathrm{~kg}$ polong kacang tanah dari $23,3 \%$ menjadi $14 \%$ dengan kecepatan pengeringan 3,9\% per jam. Pengering infrared dalam penelitian ini mampu meningkatkan kecepatan pengeringan dibandingkan dengan penelitian lain.

Data kadar air pada Gambar 2 dirubah ke dalam berat kering dan dimasukkan pada Persamaan (5) untuk menentukan nilai moisture ratio-nya. Nilai konstanta dan parameter pengeringan tiap-tiap model pada Persamaan (1) hingga Persamaan 4) disajikan pada Tabel 2 berikut.

Tabel 2. Nilai konstanta dan parameter Model Page

\begin{tabular}{|c|c|c|c|c|c|}
\hline \multirow{2}{*}{ Model } & \multicolumn{5}{|c|}{ Konstanta dan Koefesien Pengeringan } \\
\hline & $\mathrm{K}$ & A & $\mathrm{N}$ & $\mathrm{B}$ & $\mathrm{R}^{2}$ \\
\hline \multicolumn{6}{|l|}{ Newton } \\
\hline SK12 & 0,921 & & & & 0,999 \\
\hline SK24 & 0,615 & & & & 0,963 \\
\hline PK12 & 0,473 & & & & 0,982 \\
\hline PK24 & 0,412 & & & & 0,949 \\
\hline KT12 & 0,476 & & & & 0,994 \\
\hline KT24 & 0,340 & & & & 0,991 \\
\hline \multicolumn{6}{|c|}{ Hendrson-Pabis } \\
\hline SK12 & 0,922 & 1,001 & & & 0,999 \\
\hline SK24 & 0,633 & 1,036 & & & 0,965 \\
\hline PK12 & 0,489 & 1,036 & & & 0,984 \\
\hline PK24 & 0,437 & 1,065 & & & 0,957 \\
\hline KT12 & 0,478 & 1,005 & & & 0,994 \\
\hline KT24 & 0,334 & 0,985 & & & 0,991 \\
\hline \multicolumn{6}{|l|}{ Page } \\
\hline SK12 & 0,905 & & 1,046 & & 0,999 \\
\hline SK24 & 0,420 & & 1,584 & & 0,995 \\
\hline PK12 & 0,350 & & 1,348 & & 0,999 \\
\hline PK24 & 0,249 & & 1,553 & & 0,988 \\
\hline KK12 & 0,472 & & 1,010 & & 0,994 \\
\hline KK24 & 0,388 & & 0,882 & & 0,995 \\
\hline \multicolumn{6}{|l|}{ Logarithmic } \\
\hline SK12 & 0,850 & 1,031 & & $-0,033$ & 0,999 \\
\hline SK24 & 0,375 & 1,323 & & $-0,308$ & 0,987 \\
\hline PK12 & 0,358 & 1,183 & & $-0,164$ & 0,993 \\
\hline PK24 & 0,296 & 1,282 & & $-0,237$ & 0,968 \\
\hline KK12 & 0,504 & 0,986 & & 0,022 & 0,994 \\
\hline KK24 & 0,436 & 0,902 & & 0,104 & 0,997 \\
\hline
\end{tabular}

Berdasarkan nilai koefisien determinasi $\left(\mathrm{R}^{2}\right)$ terlihat bahwa Model Page memberikan nilai $\mathrm{R}^{2}$ paling tinggi diantara model yang lain, artinya Model Page lebih dapat mewakili kinetika pengeringan ketiga bahan pertanian tersebut. Beberapa hasil penelitian lain juga memperlihatkan bahwa Model Page dianggap cukup mempresentasikan mekanisme pengeringan irisan singkong (Wilaipon, 2013; Kajuna dkk., 2001), irisan pisang (Faal dkk., 2013) dan kacang (Kashaninejad dkk., 2007).

Nilai konstanta $\mathrm{K}$ pada kapasitas $12 \mathrm{~kg}$ lebih besar daripada kapasitas $24 \mathrm{~kg}$. Artinya dengan peningkatan kapasitas maka nilai moisture ratio-nya semakin besar yang menunjukkan nilai kadar airnya lebih tinggi. Hasil ini sesuai dengan hasil penelitian Kajuna dkk. (2001), pada pengeringan irisan singkong ketebalan $5 \mathrm{~mm}$ temperatur $55{ }^{\circ} \mathrm{C}$ dimana kapasitas pengeringan divariasikan pada 100 g, 200 g, dan 300 g. Hasil menunjukkan nilai konstanta K Model Page semakin turun seiring kenaikan ketebalan lapisan dengan nilai konstanta $\mathrm{K}$ berkisar antara $0,71-0,91$ dan parameter $\mathrm{N}$ sebesar 0,061-0,124.

Dengan memasukkan nilai konstanta $\mathrm{K}$ dan parameter $\mathrm{N}$ pada Persamaan (3) maka nilai MR prediksi dapat ditentukan untuk setiap waktu seperti terlihat pada Tabel 3. Perbandingan antara moisture ratio (MR) data eksperimen dan hasil persamaan Model Page pada Tabel 3 dapat dilihat pada Gambar 3 sampai 5.

Berdasarkan Gambar 3, 4, dan 5 terlihat bahwa nilai MR eksperimen mendekati nilai MR persamaan Model Page. Grafik ini semakin mempertegas bahwa Model Page cukup representatif untuk menggambarkan kinetika pengeringan lapisan-tipis irisan singkong, pisang, dan kacang tanah.

Hasil penelitian Faal dkk. (2013) memperlihatkan Model Page paling representatif untuk pengeringan irisan pisang dengan ketebalan $3 \mathrm{~mm}$ menggunakan gas buang mesin generator pada berbagai beban, dimana pada beban penuh nilai konstanta $\mathrm{K}$ sebesar 0,048 dan $\mathrm{N}$ sebesar 1,015. Pengeringan irisan singkong sebanyak $2,5 \mathrm{~kg}$ pada temperatur $70{ }^{\circ} \mathrm{C}$ menggunakan microwave memberikan nilai konstanta $\mathrm{K}$ sebesar 0,603 dan parameter $\mathrm{N}$ sebesar 0,976 (Wilaipon,

Tabel 3. Persamaan pengeringan singkong, pisang, dan kacang tanah berdasarkan Model Page

\begin{tabular}{cc}
\hline Perlakuan & MR Prediksi Model Page \\
\hline SK12 & MR $=\exp \left(-0,90 *^{*} \mathrm{t}^{1,046}\right)$ \\
SK24 & MR $=\exp \left(-0,420 * \mathrm{t}^{1,584}\right)$ \\
PK12 & MR $=\exp \left(-0,350 * \mathrm{t}^{1,348}\right)$ \\
PK24 & MR $=\exp \left(-0,249 * \mathrm{t}^{1,553}\right)$ \\
KK12 & MR $=\exp \left(-0,472 * \mathrm{t}^{1,010}\right)$ \\
KK24 & MR $=\exp \left(-0,388 * \mathrm{t}^{0,882}\right)$ \\
\hline
\end{tabular}




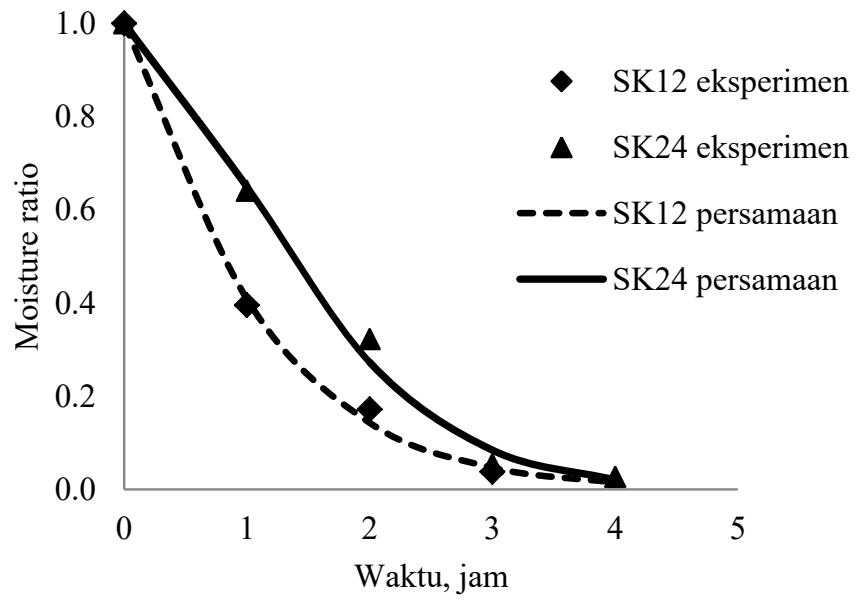

Gambar 3. Moisture ratio data eksperimen dan Model Page irisan singkong

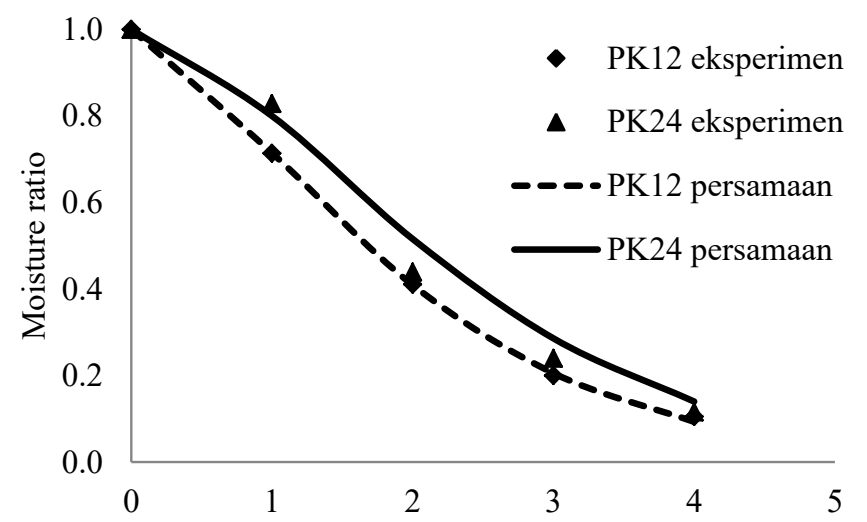

Waktu, jam

Gambar 4. Moisture ratio data eksperimen dan Model Page irisan pisang

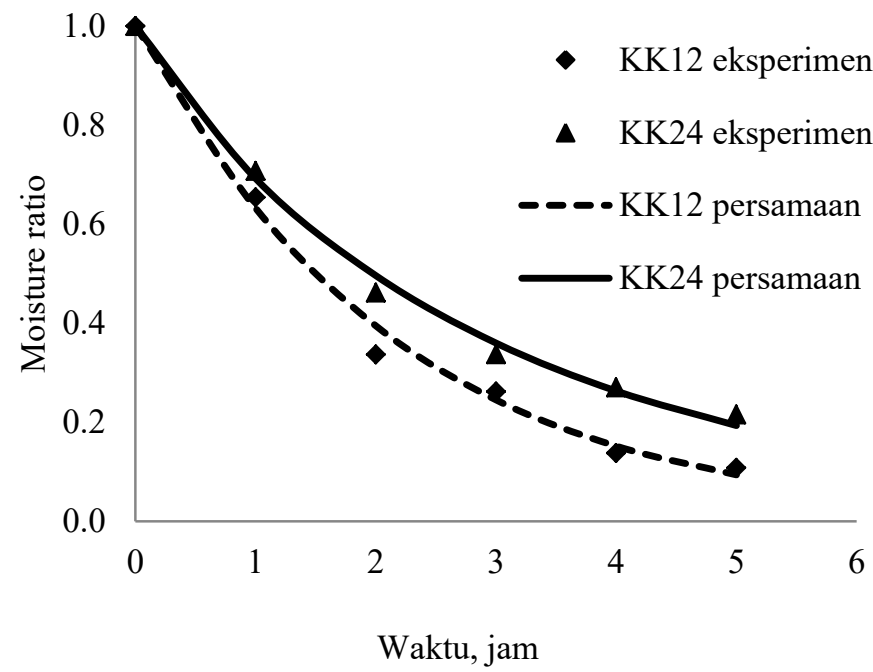

Gambar 5. Moisture ratio (MR) data eksperimen dan Model Page kacang tanah
Tabel 4. Nilai effective moisture diffusivity $\left(\mathrm{D}_{\text {eff }}\right)$ pengeringan singkong, pisang, dan kacang tanah

\begin{tabular}{cccc}
\hline Perlakuan & $\mathrm{D}_{\text {eff }}, \mathrm{m}^{2} /$ detik & $\mathrm{R}^{2}$ & SEE \\
\hline SK12 & $2,71 \mathrm{E}-10$ & 0,98 & 0,24 \\
SK24 & $2,46 \mathrm{E}-10$ & 0,95 & 0,41 \\
PK12 & $1,47 \mathrm{E}-10$ & 0,98 & 0,12 \\
PK24 & $1,34 \mathrm{E}-10$ & 0,95 & 0,22 \\
KK12 & $3,23 \mathrm{E}-10$ & 0,99 & 0,12 \\
KK24 & $2,11 \mathrm{E}-10$ & 0,99 & 0,08 \\
\hline
\end{tabular}

2013). Model Page juga dapat merepresentasikan pengeringan kacang pistachio (Pistacia vera) pada temperatur $55^{\circ} \mathrm{C}, \mathrm{RH}$ $20 \%$, dan kecepatan aliran udara $0,5 \mathrm{~m} / \mathrm{s}$ yang memberikan nilai konstanta $\mathrm{K}$ sebesar 0,016 dengan parameter $\mathrm{N}$ sebesar 0,874 (Kashaninejad dkk., 2007)

Pengeringan bahan makanan sebagian besar terjadi pada periode falling rate dan transfer air selama periode ini dikendalikan oleh difusi internal. Analisis pada periode ini dilakukan untuk memahami kinetika pengeringan dengan penentuan difusivitas efektif $\left(\mathrm{D}_{\text {eff }}\right)$ sesuai Persamaan (8) (Khawas dkk., 2014). Hasil perhitungan nilai $\mathrm{D}_{\text {eff }}$ untuk semua perlakuan disajikan pada Tabel 4.

Moisture diffusivity menggambarkan migrasi atau difusi air dalam produk pertanian selama operasi pengeringan yang merupakan fungsi kadar air, temperatur, dan struktur bahan (Abano dan Sam-Amoah, 2011). Nilai effective moisture diffusivity untuk ketiga bahan pertanian pada kisaran 1,34 x $10^{-10} \mathrm{~m}^{2} /$ detik - 3,23 x $10^{-10} \mathrm{~m}^{2} /$ detik untuk kapasitas 12-24 kg. Nilai koefisien difusivitas tersebut mempunyai kecenderungan yang sama, pada kapasitas yang lebih kecil nilai difusivitas efektifnya akan lebih besar. Nilai ini sesuai dengan kisaran umum untuk bahan makanan sebesar $10^{-12} \mathrm{~m}^{2} /$ detik sampai 10-8 $\mathrm{m}^{2} /$ detik (Zogzas dkk., 1996 dalam Omolola dkk., 2015).

Perbedaan nilai difusivitas antara komoditas pertanian dimungkinkan karena perbedaan struktur bahan yang dikeringkan termasuk perbedaan ketebalan bahan. Dengan ketebalan irisan yang sama, nilai difusivitas irisan pisang lebih kecil daripada irisan singkong. Hal yang sama ditunjukkan oleh Fernando dkk. (2011), lebih kecilnya nilai difusivitas irisan pisang dimungkinkan karena sifat lengket daging pisang yang membatasi gerakan air dalam bahan.

Beberapa penelitian lain menunjukkan bahwa nilai effective moisture diffusivity dalam kacang tanah pada pengeringan menggunakan pengering conection air-forced pada temperatur $60^{\circ} \mathrm{C}$ sebesar $7,90 \times 10^{-11} \mathrm{~m}^{2} /$ detik dan $2,48 \times 10$ ${ }^{10} \mathrm{~m}^{2} /$ detik masing-masing untuk varietas black bambara dan white bambara (Kapsto dkk., 2013). Operasi pengeringan 
irisan pisang luvhele pada temperatur $40-60{ }^{\circ} \mathrm{C}$ memberikan nilai effective moisture diffusivity sebesar $1,80 \times 10^{-11} \mathrm{~m}^{2} /$ detik2,28x10-11 $\mathrm{m}^{2} /$ detik (Omolola dkk., 2015). Hasil penelitian Ajala dkk. (2012) menunjukkan pengeringan irisan singkong dalam tunnel dryer pada temperatur $60-80{ }^{\circ} \mathrm{C}$ memberikan nilai effective moisture diffusivity berkisar dari $2,43 \times 10^{-11} \mathrm{~m}^{2} /$ detik sampai $4,52 \times 10^{-11} \mathrm{~m}^{2} /$ detik.

\section{KESIMPULAN}

Kinetika pengeringan irisan singkong, pisang, dan polong kacang tanah dalam pengering inframerah telah dipelajari pada dua kapasitas $12 \mathrm{~kg}$ dan $24 \mathrm{~kg}$. Peningkatan kapasitas menurunkan kecepatan pengeringan pada semua komoditas pertanian yang diuji. Data yang diperoleh diujikan dengan empat model semi-empiris yaitu model Newton, Henderson-Pabis, Page, dan Logarithmic. Berdasarkan nilai koefiesien determinasi $\left(\mathrm{R}^{2}\right)$ Model Page memberikan hasil yang paling tinggi, artinya Model Page merupakan model yang paling mendekati dengan data eksperimental untuk semua komoditas pertanian yang diujikan. Nilai K Model Page untuk pengeringan singkong kapasitas $12 \mathrm{~kg}$ dan $24 \mathrm{~kg}$, pisang kapasitas $12 \mathrm{~kg}$ dan $24 \mathrm{~kg}$, dan kacang tanah kapasitas $12 \mathrm{~kg}$ dan $24 \mathrm{~kg}$ bertutut-turut sebesar 0,905, 0,420, 0,350, $0,249,0,472$, dan 0,388 dengan nilai $\mathrm{N}$ berturut-turut sebesar $1,046,1,584,1,383,1,553,1,010,0,882$. Nilai effective moisture diffusivity pada proses pengeringan ini adalah 2,71 x $10^{-10} \mathrm{~m}^{2} /$ detik, 2,46 x $10^{-10} \mathrm{~m}^{2} /$ detik, $1,47 \times 10^{-10} \mathrm{~m}^{2} /$ detik, $1,34 \times 10^{-10} \mathrm{~m}^{2} /$ detik, $3,23 \times 10^{-10} \mathrm{~m}^{2} /$ detik, dan $2,11 \times 10^{-10} \mathrm{~m}^{2} /$ detik masing-masing untuk pengeringan singkong kapasitas $12 \mathrm{~kg}$ dan $24 \mathrm{~kg}$, pisang kapasitas $12 \mathrm{~kg}$ dan $24 \mathrm{~kg}$, dan kacang tanah kapasitas $12 \mathrm{~kg}$ dan $24 \mathrm{~kg}$.

\section{Daftar Simbol}

$\begin{array}{ll}M R & =\text { moisture ratio (rasio kadar air) } \\ M_{t} & =\text { kadar air saat waktu } \mathrm{t}(\%) \\ M_{i} & =\text { kadar air awal }(\%) \\ M_{e} & =\text { kadar air kesetimbangan }(\%) \\ t & =\text { waktu pengeringan (jam) } \\ K & =\text { konstanta pengeringan } \\ N & =\text { parameter pangkat pengeringan } \\ A, B & =\text { parameter-parameter pengeringan } \\ D_{\text {eff }} & =\text { effective moisture diffusivity }\left(\mathrm{m}^{2} / \text { detik) }\right. \\ L & =\text { setengah tebal produk (m) } \\ \mathrm{n} & =1,2,3 \ldots . .5 \\ R^{2} & =\text { koefisien determinasi } \\ \mathrm{SEE} & =\text { standard error of estimation } \\ S K 12 & =\text { singkong (ubi kayu) kapasitas } 12 \mathrm{~kg} \\ S K 24 & =\text { singkong (ubi kayu) kapasitas } 24 \mathrm{~kg} \\ P K 12 & =\text { pisang kapasitas } 12 \mathrm{~kg}\end{array}$
$P K 24=$ pisang kapasitas $24 \mathrm{~kg}$
$K K 12=$ kacang tanah kapasitas $12 \mathrm{~kg}$
$K K 24=$ kacang tanah kapasitas $24 \mathrm{~kg}$
$\mathrm{Mr}_{\text {pre }}=$ moisture ratio prediksi
$\mathrm{Mr}_{\text {exp }}=$ moisture ratio eksperimental

\section{UCAPAN TERIMA KASIH}

Ucapan terima kasih kepada Pusbang TTG-LIPI sebagai penyandang dana kegiatan penelitian melaui program Perancangan Pengering Infrared Serbaguna Berbahan Bakar Biogas untuk Pengeringan Produk Pertanian, rekan-rekan peneliti dan teknisi yang tergabung dalam kegiatan penelitian ini.

\section{DAFTAR PUSTAKA}

Abano, E.E. dan Sam-Amoah, L.K. (2011). Effects of different pretreatments on drying characteristics of banana slices. ARPN Journal of Engineering and Applied Sciences 6 (3): 121-129.

Aghbashlo, M., Kianmehr, M.H., Arabhosseini, A. dan Nazghelichi, T.( 2011). Modelling the carrot thin-layer drying in a semi-industrial continous band dryer. Czech Journal Food Science 5(29): 528-538.

Ahmad, M. dan Mirani, A.A. (2012). Heated air drying of groundnut. Pakistan Journal Agricultural Research 25 (4): 272-279.

Ajala, A.S., Aboiye, A.O, Popoola, J.O., Adeyanju, J.A. (2012). Drying characteristics and mathematical modelling of cassava chips. Chemical and Process Engineering Research Vol 4. http:/www.iiste.org/ Journals/index.php/CPER/article/view/3178. [Diakses 18 Januari 2015].

Aregbesola, O.A., Ogunsina, B.S., Sofolahan, A.E. dan Chime. N.N. (2015). Mathematical modeling of thin layer drying characteristics of dika (Irvingia gabonensis) nuts and kernels. Nigerian Food Journal 33: 83-89.

Botelho, F.M., Corrêa, P.C., Goneli, A.L.D., Martins, M.A., Magalhaes, F.E.A. dan Campos, S.C. (2011). Periods of constant and falling-rate for infrared drying of carrot slices. Revista Brasileira de Engenharia Agrícola e Ambiental (Agriambi) 15(8): 845-852.

Biro Pusat Statistik (2015). Produksi Tanaman Pangan 2014. http://www.bps.go.id/index.php/publikasi/1103. [Diakses 12 Januari 2015]. 
Brooker, D.B., Bakker-Arkema, F.W., Hall, C.W. (1992). Drying and Storage of Grains and Oilseeds. Westport: The AVI Publishing Company, 450p.

Brooks, M.S., Abou El-Hana, N.H. dan Ghaly, A.E. (2008). Effects of tomato geometries and air temperature on the drying behaviour of plum tomato. American Journal of Applied Sciences 5: 1369-1375.

Diamante, L.M., dan Munro, P.A. (1993). Mathematical modelling of the thin layer solar drying of sweet potato slices. Solar Energy 51: 271-276.

Doymaz, I. (2013). Determination of infrared drying characteristics and modelling of drying behaviour of carrot pomace. Journal of Agricultural Sciences 19: 4453.

Faal, S., Tavakoli, S., Ghobadian, B., Samadi, G.N.H. dan Zarein, M. (2013). Mathematical modeling of dried banana slices with MCHP dyer. Global Journal of Researches in Engineering Mechanical and Mechanics Engineering 13(5): 48-55.

Fernando, W.J.N., Low, H.C. dan Ahmad, A.L. (2011). The effect of infrared on diffusion coefficients and activation energies in convective drying: A case study for banana, cassava and pumpkin. Journal of Apllied Sciences 11(21): 3635-3639.

Hanum, F., Kaban, I.M.D. dan Tarigan, M.A. (2012). Ekstraksi pektin dari kulit buah pisang raja (Musa sapientum). Jurnal Teknik Kimia USU 1(2): 21-26.

Kajuna, S.T.A.R, Silayo, V.C.K., Mkenda, A. dan Makungu, P.J.J. (2001). Thin-layer drying of diced cassava roots. African Journal of Science and Technology 2(2): 94100.

Kapsto, K.G., Njintang, Y.N., Nguemtchouin, M.M.G., Scher, J., Hounhouigan, J. dan Mbofung, C.M.F. (2013). Drying kinetics of two varietas of bambara groundnuts (Vigna subterranea) seeds. Journal of Food Technology 11(2): 30-37.

Kashaninejad, M., Mortazavi, A., Safekordi, A. dan Tabil, L.G. (2007). Thin-layer drying characteristics and modeling of pistachio nuts. Journal of Food Engineering 78: 98108.

Khawas, P., Das, A.J., Dash, K.K. dan Deka, S.C. (2014). Thin-layer drying characteristics of Kachkal banana peel (Musa ABB) of Assam, India. International Food Research Journal 21(3): 1011-1018.

Koswara, S. (2009). Teknologi tepat guna pengolahan singkong, pisang dan talas. http://tekpan.unimus.ac.id/ wp-content/uploads/2013/07/TEKNOLOGI-TEPATGUNA-PISANG-SINGKONG-DAN-TALAS.pdf [Diakses 22 Oktober 2010].
Laohavanich, J. dan Wongpichet, S. (2008). Thin layer drying model for gas-fired infrared drying of paddy. Songklanakarin Journal Science Technology 30(3): 343-348.

Motevali A., Minaei S., Khoshtaghaza, M.H. dan Amirnejat, H. (2011). Comparison of energy consumption and specific energy requirements of different methods for drying mushroom slices. Energy 36: 6433-6441.

Motevali, A., Minaei, S., Banakar, A., Ghobadian, B. dan Khoshtaghaza. M.H. (2014). Comparison of energy parameters in various dryers. Jurnal Energy Conversion and Management 87: 711-725.

Nowak, D. dan Lewicki, P.P. (2004). Infrared drying of apple slices. Innovative Food Science Emerging Technologies 5: $353-360$.

Omolola, A.O., Jideani, A.I.O. dan Kapila, P.F. (2015). Modelling of thin layer drying characteristics of banana CV. Luvhelle. Bulgarian Journal of Agricultural Science 21(2): 342-348.

Palupi, H.T. (2012). Pengaruh jenis pisang dan bahan perendam terhadap karakteristik tepung pisang (Musa Spp). Jurnal Teknologi Pangan 4(1): 102-120.

Ponkham, K., Meesoa, N., Soponronnarit, S. dan Siriamornpun, S. (2012). Modeling of combined far-infrared radiation and air drying of a ring shaped-pineapple with/without shrinkage. Food and Bioproducts Processing 90: 155164.

Saputra, A.E. (2014). Pengeringan Lapisan Tipis Kacang Tanah Utuh dan Biji Kacang Tanah (Arachis hypogeae L) Varietas Gajah. Skripsi. Fakultas Pertanian. Universitas Hasanuddin, Makassar.

Sharma, G.P., Verma, R.C. dan Pathare P.B. (2005). Thinlayer infrared radiation drying of onion slices. Journal of Food Engineering 67: 361-366.

Shi, J., Pan, Z., McHugh, T.H., Wood, D., Hirschberg, E. dan Olson, D. (2008). Drying and quality characteristics of fresh and sugar-infused blueberries dried with infrared radiation heating. Jurnal LWT-Food Science and Technology 41: 1962-1972.

Silvia, E. dan Yuwana. (2012). Kinerja prototipe pengering energi surya model YSD-UNIB12 dalam mengeringkan singkong. Prosiding Seminar Nasional Fakultas Pertanian. Universitas Bengkulu, Bengkulu.

Swasdisevi, T., Devahastin, S., Ngamchum, R. dan Soponronnarit, S. (2007). Optimization of a drying process using infrared vacuum drying of cavendish banana slices. Songklanakarin Journal Science Technology 29(3): 809-816. 
Udoro, E.O., Gbadamosi, O.S. dan Taiwo, K.A. (2008). Studies on the production and utilization of dried cassava chips as human food. http://iufost.org/iufostftp/ Elohor\%20Chapter\%2017.pdf. [Diakses 13 Mei 2016].

Wilaipon, P. (2013). Cassava chip drying by using a smallscale hot-air microwave oven. American Journal of Engineering and Applied Sciences 6(2): 211-215.
Zogzas, N.P., Maroulis, Z.B. dan Marinos-Kouris, D. (1996). Moisture diffusivity data compilation in foodstuffs. Drying Technology 14: 2225-2253. 